Article

\title{
Cause of Death: Phytophthora or Flood? Effects of Waterlogging on Phytophthora medicaginis and Resistance of Chickpea (Cicer arietinum)
}

\author{
Nicole Dron ${ }^{1,2, * \mathbb{D}}$, Steven Simpfendorfer ${ }^{1}$, Tim Sutton ${ }^{2,3}$, Georgina Pengilley ${ }^{1}$ and Kristy Hobson ${ }^{1}$ \\ 1 NSW Department of Primary Industries, 4 Marsden Park Road, Tamworth, NSW 2340, Australia; \\ steven.simpfendorfer@dpi.nsw.gov.au (S.S.); georgina.penilley@dpi.nsw.gov.au (G.P.); \\ kristy.hobson@nsw.dpi.nsw.gov.au (K.H.) \\ 2 School of Agriculture, Food and Wine, University of Adelaide, PMB 1, Glen Osmond, SA 5064, Australia; \\ timothy.sutton@adelaide.edu.au \\ 3 South Australian Research and Development Institute, Adelaide, SA 5001, Australia \\ * Correspondence: nicole.dron@dpi.nsw.gov.au
}

check for updates

Citation: Dron, N.; Simpfendorfer, S.; Sutton, T.; Pengilley, G.; Hobson, K. Cause of Death: Phytophthora or Flood? Effects of Waterlogging on Phytophthora medicaginis and Resistance of Chickpea (Cicer arietinum). Agronomy 2022, 12, 89. https://doi.org/10.3390/ agronomy12010089

Academic Editor: Valeria Cavallaro

Received: 2 December 2021

Accepted: 28 December 2021

Published: 30 December 2021

Publisher's Note: MDPI stays neutral with regard to jurisdictional claims in published maps and institutional affiliations.

Copyright: (C) 2021 by the authors. Licensee MDPI, Basel, Switzerland. This article is an open access article distributed under the terms and conditions of the Creative Commons Attribution (CC BY) license (https:// creativecommons.org/licenses/by/ $4.0 /)$.

\begin{abstract}
Chickpea production in Australia is constrained by both waterlogging and the root disease Phytophthora root rot (PRR). Soil saturation is an important pre-condition for significant disease development for many soil-borne Phytophthora spp. In wet years, water can pool in low lying areas within a field, resulting in waterlogging, which, in the presence of PRR, can result in a significant yield loss for Australian chickpea varieties. In these circumstances, the specific cause of death is often difficult to discern, as the damage is rapid and the spread of PRR can be explosive in nature. The present study describes the impact of soil waterlogging on oxygen availability and the ability of $P$. medicaginis to infect chickpea plants. Late waterlogging in combination with PRR reduced the total plant biomass by an average of $94 \%$; however, waterlogging alone accounted for $88 \%$ of this loss across three reference genotypes. Additional experiments found that under hypoxic conditions associated with waterlogging, P. medicaganis did not proliferate as determined by zoospore counts and DNA detection using qPCR. Consequently, minimizing waterlogging damage through breeding and agronomic practices should be a key priority for integrated disease management, as waterlogging alone results in plant stunting, yield loss and a reduced resistance to PRR.
\end{abstract}

Keywords: soil-borne disease; pulse; phenotyping; breeding; agronomy

\section{Introduction}

Chickpea (Cicer arietinum) was first domesticated 10,000 to 12,000 years ago in the arid to semi-arid Middle-East and has since been integrated into many cropping systems internationally [1,2]. Australia has become the second-largest exporter of chickpea globally following its introduction in the 1970s [3,4]. The global population is increasing, and with environmental shifts induced by climate change, food security is being challenged. Chickpea is an important staple source of protein in south-east Asian countries, and demand for plant protein is increasing [5]. The sustainable production of plant protein is dependent on plants' resilience to abiotic and biotic stress, and the frequency of severe weather events including flooding and drought is expected to increase, posing a threat to global food production into the future $[6,7]$.

The northern cropping region (northern New South Wales and southern Queensland) is the primary chickpea production region in Australia. Phytophthora root rot (PRR) caused by the soil-borne oomycete Phytophthora medicaginis is endemic to this region, and yield losses of over $70 \%$ can occur during seasons when above average rainfall is experienced [8]. Soil-borne Phytophthora spp. sporulate under high soil moisture conditions, releasing motile zoospore that rapidly infect roots, causing severe disease pressure across vast 
areas [9]. Phytophthora spp. are obligate aerobes, and during periods of soil saturation in many circumstances it is difficult to decipher whether the crop damage is from PRR, waterlogging or a combination of both $[10,11]$. Extensive damage may be caused primarily by waterlogging, as most crop species exhibit a physical effect and become physiologically constrained, which in turn reduces the plants' ability to overcome stress [12,13]. Evidence from other pathosystems indicates that there is a possibility that PRR management could be improved though minimizing the impact of waterlogging, as waterlogging contributes to disease development and yield loss in chickpea [14], as previously reported in soybean (Glycine max) [15].

P. medicaginis inoculum can survive for up to five years between chickpea crops, either dormant in the soil as oospore and chlamydospore structures or hosted on other medic weed species [10]. There is currently no economic control of PRR and growers are advised to avoid fields prone to waterlogging and low-lying areas with a history of PRR [9]. The level of PRR infection can be reduced early through the repeated application of the short acting fungicide active metalaxyl, but this practice is uneconomical at the broadacre scale [9]. Hence, improving the genetic resistance to PRR remains a high priority for chickpea breeding in Australia [16]. Waterlogging is becoming a greater risk to crop production across Australia, with sporadic high rainfall events during the growing season and depreciating soil structure caused by prior flood events and farming practices inundating plants for days or weeks $[17,18]$. Breeding and agronomic practices to prevent severe PRR disease in high rainfall conditions may benefit from a shift in focus from plants' selection for PRR resistance alone to also include their genetic tolerance and the prevention of waterlogging for integrated disease management [14].

Genetic diversity in cultivated chickpea is narrow in comparison to other crops, and whilst there are many wild Cicer accessions, only C. echinospermum P.H. Davis and C. reticulatum Ladizinsky can successfully be crossed to cultivated chickpea (C.arietinum). Wild Cicer accessions can offer desirable agronomic traits for pyramiding and improved disease resistance but present major challenges to breeding that are associated with agronomic genetic lag [19]. To date, little waterlogging tolerance has been discovered in cultivated or wild chickpea $[12,20,21]$. Sourcing wild Cicer accessions with beneficial root traits, which infer waterlogging tolerance and PRR resistance, is ongoing [14,22]. Agronomic practices such as soil amelioration and incorporating large deep rooting crops into the farming system can improve the soil structure and water filtration, thus also reducing the risk of waterlogging. Preventing the pooling of water and soil saturation within fields could in turn reduce $P$. medicaginis inoculum bursts near sensitive chickpea primary root systems $[10,23]$, whilst also allowing plants to maintain their normal metabolism (i.e., plant defence responses).

This study investigated the effect of waterlogging on P. medicaganis infection of chickpea in three controlled-environment experiments. Three hypotheses were tested: (1) waterlogging alone is as severely damaging to plants' growth as infection by P. medicaginis (Exp 1); (2) transient flooding increases $P$. medicaginis inoculum production, whilst waterlogging has an inhibitory effect (Exp 2); and (3) P. medicaginis inoculum production under waterlogged conditions is associated with hypoxic conditions (Exp 3).

\section{Materials and Methods}

\subsection{Plant and Oomycete Material}

Data are presented for three desi chickpea genotypes that differ in their susceptibility to PRR in all three experiments of this study: the moderately PRR resistant wild C. echinospermum backcross (BC), genotype 04067-81-2-1-1 (04067) (pedigree: Howzat/ILWC 245/ /99039-1013); the moderately susceptible C. arietinum Yorker (pedigree: 8507-28H)/946-31); and the very susceptible Rupali (pedigree: FLIP84-15C/ICCV88516//Amethyst) [24]. The northern region $P$. medicaginis isolate TR4046 was used in each study, recovered from a PRR-infected chickpea plant near Moree, New South Wales in 2005. The isolate was cul- 
tured on V8 agar and a mycelial-oospore suspension prepared for inoculation as described by Dron et al., 2021.

\subsection{Experiment 1: Effect of Early and Late Waterlogging on Phytophthora Root Rot in Chickpea}

\subsubsection{Design and Conditions}

Experiment 1 (Exp 1) was established in a shade house at the Tamworth Agricultural Institute, NSW (TAI) on 29 June 2020. The six treatments included: a nil control (no PRR or waterlogging); PRR infection; early waterlogging; late waterlogging; and combined treatments of PRR infection with early or late waterlogging. Each experiment consisted of four replicates in a factorial split plot design, with waterlogging $(n=3) \times P$. medicaginis inoculation $(n=2)$ as the main plot treatment level and chickpea genotypes $(n=8)$ the subplot treatment level. The three chickpea genotypes (04067, Yorker and Rupali) were tested against five other advanced chickpea genotypes randomized in each deep pot. Data from the advanced breeding genotypes were used in the analysis but are not presented in this study due to commercial in-confidence reasons.

\subsubsection{In Planta Waterlogging and Inoculation}

Pre-moistened and sieved $(10 \mathrm{~mm})$ potting media $\left(1: 1: 1 \mathrm{loam}\right.$, sand and Greenlife ${ }^{\circledR}$ (Perth, Australia) with Pacific Fertiliser ${ }^{\circledR}$ (Tugun, Australia) Super Fine Ag lime $(6.25 \% w / v)$ were packed into Handy ${ }^{\circledR}$ (Keysborough, Australia) $100 \mathrm{~L}$ wheelie bins used as deep pots (Figure 1). The potting media's pH of $7.6 \pm 0.03$ was determined by agitating 1:5 media to water for $1 \mathrm{~h}$ before measuring with a handheld $\mathrm{pH}$ meter $\left(\mathrm{pH} 10\right.$, Oakton ${ }^{\circledR}$, Vernon Hills, IL, USA). Potting mix used in all experiments was determined to be free of P. medicaginis and other pathogens of chickpea by testing soil media with PREDICTA ${ }^{\circledR} \mathrm{B}$ (Adelaide, Australia) soil borne disease DNA test panel performed by the South Australian Research and Development Institute (SARDI), South Australia (https://pir.sa.gov.au/ research/services/molecular_diagnostics/predicta_b, (accessed on 15 March 2021)). Soil moisture probes (EP100GL-80, Eviropro ${ }^{\circledR}$, Golden Grove, Australia) were inserted into representative control, early and late waterlogging treatments to determine the timing of manual watering (2-3 L rainwater) at approximately $80 \%$ field capacity $20 \mathrm{~cm}$ below the soil surface. Water holding capacity of potting media was determined using a modified version of the Schwenke et al. [25] method to calibrate moisture probes. All bins were initially flooded for $24 \mathrm{~h}$ then drained for $48 \mathrm{~h}$ prior to sowing. Seed was sterilized with $0.04 \%(w / v)$ sodium hypochlorite for $2 \mathrm{~min}$ and triple rinsed prior to sowing at $10 \mathrm{~cm}$ alongside rhizobium inoculum using Nodulaid ${ }^{\circledR}$ (Southbank, Australia) peat slurry at the recommended rate. Plants were double sown and thinned post-emergence at the four-leaf stage. After eight weeks, all plants were fertilized fortnightly with $30 \mathrm{~mL}$ Yates ${ }^{\circledR}$ (Clayton, Australia) Thrive soluble all-purpose fertilizer at the recommended concentration. Plants were staked and clipped as required to ensure they remained upright.

Four weeks after sowing, PRR treatments were applied at a target rate of 500 oospores/plant in furrows adjacent to seedlings at the five-leaf stage. Early waterlogging treatments were applied after one week and late waterlogging treatments five weeks after PRR inoculation, during the early and late vegetative phase, respectively. Waterlogging treatments were sustained for five weeks by maintaining water level to the soil surface daily. Visual chlorosis scores (1 green and healthy-9 chlorotic and dead) were taken two weeks after the late waterlogging treatment was completed. Once the control treatment had senesced, the experiment was desiccated with glyphosate (RoundUp ${ }^{\circledR}$ Baulkham Hills, Australia) at $7.2 \mathrm{~g} / \mathrm{L}$. All other measurements, including plant height, adventitious root count as described in Dron et al. (2021), root disease score (1 healthy-9 dead), nodulation scored using a modified method from Corbin et al. [26] (1 no nodulation-5 extensive nodulation), reproductive node count, total biomass (root and shoot) and seed weight, were taken at harvest on 19 October 2020. Biomass (root and shoot) measurements were taken after drying at $70{ }^{\circ} \mathrm{C}$ for $48 \mathrm{~h}$. Ambient temperature was recorded continuously (Tinytag Plus 2) and averages were reported across time-periods (day and night). Soil oxygen- 
reduction potential $(\mathrm{mV}), \mathrm{pH}$ and soil temperature were measured using a handheld, $\mathrm{pH}$, temperature and oxidation-reduction potential (ORP) meter (TPS, WP-90 Pty Ltd., Brendale, QLD, Australia). Soil temperature and ORP data were captured pre-waterlogging, midwaterlogging and post-waterlogging by measuring all field capacity, early waterlogging and late waterlogging treatment replicates for $2 \mathrm{~min}$ at a depth of $10 \mathrm{~cm}$ four times throughout the duration of the experiment.

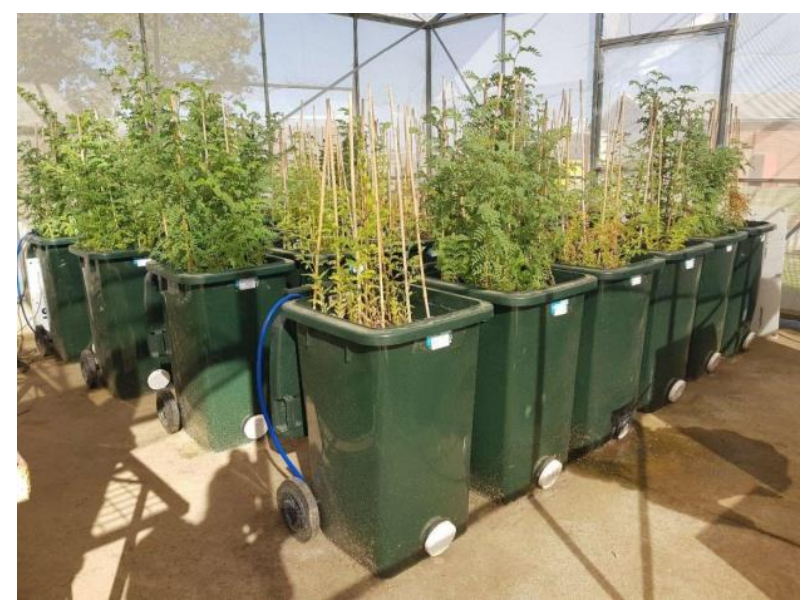

Figure 1. Wheelie bins with volume $100 \mathrm{~L}$ used as deep pots in Experiment 1 to investigate the effects of waterlogging and P. medicaganis infection on eight chickpea genotypes.

\subsection{Experiment 2: Detection of P. medicaginis DNA in Chickpea Root and Soil Media under} Transient and Long-Term Waterlogging Using qPCR

\subsubsection{Design and Conditions}

Experiment 2 (Exp 2) was conducted on seedlings of three chickpea genotypes (04067, Yorker and Rupali) in a temperature-controlled growth chamber where minimum and maximum temperatures were set diurnally $(12 \mathrm{~h})$ at $18{ }^{\circ} \mathrm{C}$ to $25^{\circ} \mathrm{C}$ at relative humidity of $30-50 \%$ (environmental control room, Percival Scientific ${ }^{\circledR}$, Perry, USA). The experiment was a randomized complete block design with six replicates of each genotype $(n=3) \times$ water and P. medicaginis treatment $(n=5)$.

\subsubsection{In Planta Waterlogging and Inoculation}

Seed was prepared as per Exp 1 and sown at $3 \mathrm{~cm}$ into $200 \mathrm{~mL}$ plastic cups containing $160 \mathrm{~g}$ pre-moistened sieved $(5 \mathrm{~mm})$ potting media. Seedlings were grown out to the two-leaf stage and P. medicaginis inoculum was applied at a concentration of 2000 oospores/ plant adjacent to the base of the seedling. Five treatments were then applied: (1) nil control (no PRR or waterlogging); (2) PRR infection and watering to $80 \%$ field capacity (FC) (nonwaterlogged); (3) initial transient waterlogging for $48 \mathrm{~h}$ post inoculation; (4) transient waterlogging for $48 \mathrm{~h}$ post inoculation and again once potting media returned to $80 \% \mathrm{FC}$; and (5) long-term waterlogging for 12 days flooding to soil surface. Pots were watered to weight and the long-term waterlogging level was maintained every 2-3 days. Data were collected from all treatments after the 12 day waterlogging treatment was completed. Fresh shoot and root weight measurements were collected along with chlorosis and root disease scores, as described in Exp 1. Roots were carefully brushed to remove loose soil prior to visual scoring and weighing and then added back to their corresponding potting mix before drying down at $40^{\circ} \mathrm{C}$ prior to submitting to SARDI (South Australia) for total (root + potting mix) P. medicaginis DNA quantification via qPCR. 
2.4. Experiment 3: Detection of P. medicaginis Zoospores and PRR in Chickpea under Hypoxic Hydroponic Conditions

\subsubsection{Design and Conditions}

Experiment 3 (Exp 3) was completed in a growth room at TAI, as described in Exp 2, using the same three genotypes 04067, Yorker and Rupali. A split plot design was used with aeration and P. medicaganis as the main plots and chickpea genotypes as the subplot treatment. The main treatments included: (1) aerated control (no PRR inoculation); (2) aeration plus PRR inoculation; and (3) hypoxia plus PRR inoculation. There were three replicates of each main treatment $(n=3)$ and a further two replicates of each genotype $(n=3)$ subplot within each main plot. Two seedlings of the three genotypes were randomized in $2.3 \mathrm{~L}$ buckets with holes in their lids and covered in black plastic to keep out light.

\subsubsection{In Planta Flooding \& Infection}

Seeds were washed in $0.04 \%(w / v)$ sodium hypochlorite for two minutes then triple rinsed before pre-germinating in darkness with 0.25 nutrient solution in reverse osmosis (RO) water over mesh. Full-strength nutrient formulae $(\mathrm{mM})$ were: $5.0 \mathrm{Ca}^{2+}, 5.0 \mathrm{~K}^{+}$, $0.625 \mathrm{NH}^{4+}, 0.4 \mathrm{Mg}^{2+}, 0.2 \mathrm{Na}^{+}, 5.4 \mathrm{SO}_{4}{ }^{2-}, 4.4 \mathrm{NO}_{3}{ }^{-}, 0.2 \mathrm{H}_{2} \mathrm{PO}_{4}{ }^{-}, 0.1 \mathrm{SiO}_{3}{ }^{2-}, 0.1 \mathrm{Fe}-$ sequestrene, $0.05 \mathrm{Cl}^{-}, 0.025 \mathrm{BO}_{3}{ }^{3-}, 0.002 \mathrm{Mn}^{2+}, 0.002 \mathrm{Zn}^{2+}, 0.0005 \mathrm{Cu}^{2+}, 0.0005 \mathrm{MoO}_{4}{ }^{2-}$ and $0.001 \mathrm{Ni}^{2+}$. The solution was buffered with $1.0 \mathrm{mM}$ MES (2-(N-morpholino) ethane sulfonic acid) $[27,28]$. The $\mathrm{pH}$ was adjusted to 6.5 using $\mathrm{KOH}$ at commencement of the experiment using a $\mathrm{pH}$ meter $\left(\right.$ Oakton $\left.{ }^{\circledR}, \mathrm{pH} 10\right)$. After six days, seedlings were transplanted into full-strength hydroponic media in $2.3 \mathrm{~L}$ buckets, and light was introduced. Seedlings were held in place with polyethylene disks and buckets topped up with RO water and agitated every $2-3$ days.

Treatments were applied to seedlings at the two-leaf stage, two days after the seedlings were transferred to buckets. Mycelial-oospore suspension was added to the inoculated treatments to provide a final solution concentration of 30 oospores $/ \mathrm{mL}$ and agitated. Nitrogen gas was bubbled through the nutrient solution of the hypoxia treatment at $170 \mathrm{~mL} / \mathrm{h}$ for three days to reduce oxygen levels $(0.3 \mathrm{ppm} \pm 0.1)$ and remained unaerated for the duration of the experiment. Control and aerated PRR treatments were continually aerated through bubbling of external air through the nutrient solution. Following three days of imposed hypoxia, nutrient solution was subsampled three times from each replicate across all treatments post agitation. Zoospores were counted from each sub-sample under a compound microscope (Leitz Wetzlar Dialux Microscope, Wetzlar, Germany) at $40 \times$ magnification using a haemocytometer. Chlorosis and root disease scores; along with fresh root and shoot weights were measured at harvest, ten days after treatment application.

\subsection{Statistical Analysis}

Data (shoot weight, biomass, root weight, root count, height, reproductive node count, nodulation, chlorosis and root disease scores) were analysed with a general linear mixed model (GLMM) using the statistical software ASReml [29] using the biometry training package [30] on R [31]. Biomass and reproductive node data were square-root transformed to ensure homogeneity of variance prior to analysis. The fixed terms in the model were the factors treatment (control, PRR and waterlogging treatments), genotype (eight genotypes for Exp 1 and three genotypes for Exp 2 and Exp 3) and their interaction. Random terms in the model were replicate and plant within replicate. P. medicaginis DNA concentrations and zoospore concentrations were also analysed using a linear mixed model, with kDNA and zoospore data transformed using a $\log 10$ transformation to ensure homogeneity of variance. Means and standard deviations for temperature and redox measures for Exp 1 over time were analysed using Microsoft Excel (2010). All data are reported as means and $5-95 \%$ confidence intervals (CI) or \pm standard deviation. 


\section{Results}

3.1. Experiment 1: Effect of Early and Late Growth Stage Waterlogging and Phytophthora Root Rot in Chickpea

Results showed that the waterlogging treatment had the largest main effect on most parameters measured in the experiment, particularly biomass $(\mathrm{F}=236, p<0.001)$ and seed weight $(\mathrm{F}=305, p<0.001)$, when compared with chickpea line $(\mathrm{F}=18, p<0.001$ \& $\mathrm{F}=33, p<0.001)$ and PRR $(\mathrm{F}=9, p<0.001 \& \mathrm{~F}=10.2 . p<0.05)$, respectively (Table 1$)$. Reductions in biomass and seed weight were observed to be associated with plant stunting and early senescence, with early waterlogging and plant death following late waterlogging treatments.

Table 1. Wald test of GLMM effects for growth and disease parameters in a three-way interaction for chickpea genotypes (C. echinospermum BC PRR moderately resistant 04067, C. arietinum PRR moderately susceptible Yorker and PRR very susceptible Rupali); water treatment (field capacity, early and late vegetative waterlogging); and uninoculated or P. medicaginis inoculated (PRR) status. F-values and the corresponding $p$-values are displayed.

\begin{tabular}{cccccccc}
\hline & Df & $\begin{array}{c}\text { Adventitious } \\
\text { Root Count }\end{array}$ & Root Disease & Nodulation & $\begin{array}{c}\text { Reproductive } \\
\text { Node }\end{array}$ & Biomass * & Seed Weight \\
\hline Water (W) & 2 & ${ }^{+} \mathrm{NS}$ & $33.2^{* * *}$ & $34.7^{* * *}$ & $145.4^{* * *}$ & $235.7^{* * *}$ & $304.5^{* * *}$ \\
PRR (P) & 1 & $5.9^{* *}$ & $10.3^{*}$ & $6.3^{*}$ & $15.1^{* * *}$ & $9.0^{* * *}$ & $10.2^{*}$ \\
Genotype (G) & 7 & $5.5^{* * *}$ & $3.0^{*}$ & $2.9^{*}$ & $13.5^{* * *}$ & $18.4^{* * *}$ & $32.7^{* * *}$ \\
$\mathrm{P} \times \mathrm{G}$ & 7 & ${ }^{+} \mathrm{NS}$ & ${ }^{+} \mathrm{NS}$ & ${ }^{+} \mathrm{NS}$ & ${ }^{\dagger} \mathrm{NS}$ & ${ }^{+} \mathrm{NS}$ & $2.5^{*}$ \\
$\mathrm{~W} \times \mathrm{P}$ & 2 & $5.6^{*}$ & ${ }^{+} \mathrm{NS}$ & ${ }^{+} \mathrm{NS}$ & $6.3^{*}$ & ${ }^{+} \mathrm{NS}$ & ${ }^{+} \mathrm{NS}$ \\
$\mathrm{W} \times \mathrm{G}$ & 14 & ${ }^{+} \mathrm{NS}$ & ${ }^{+} \mathrm{NS}$ & $3.2^{* * *}$ & $2.9^{* * *}$ & ${ }^{+} \mathrm{NS}$ & $10.0^{* * *}$ \\
$\mathrm{~W} \times \mathrm{P} \times \mathrm{G}$ & 14 & $2.6^{*}$ & $2.8^{* * *}$ & ${ }^{+} \mathrm{NS}$ & ${ }^{+} \mathrm{NS}$ & $2.1^{*}$ & $2.1^{*}$ \\
\hline
\end{tabular}

* Significant at the 0.05 probability level. ${ }^{* * *}$ Significant at the 0.001 probability level. ${ }^{\dagger}$ NS, non-significant.

None of the three genotypes examined were able to fully recover their seed weight following early and late waterlogging treatments, with late waterlogging having a more detrimental effect than early waterlogging (Table 2, Figure 2a) due to a significantly greater root disease incidence under waterlogging conditions (Table 2, Figure 2b).

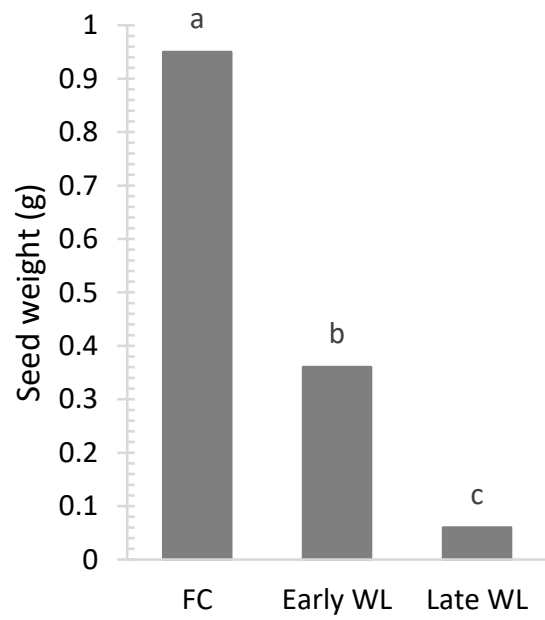

(a)

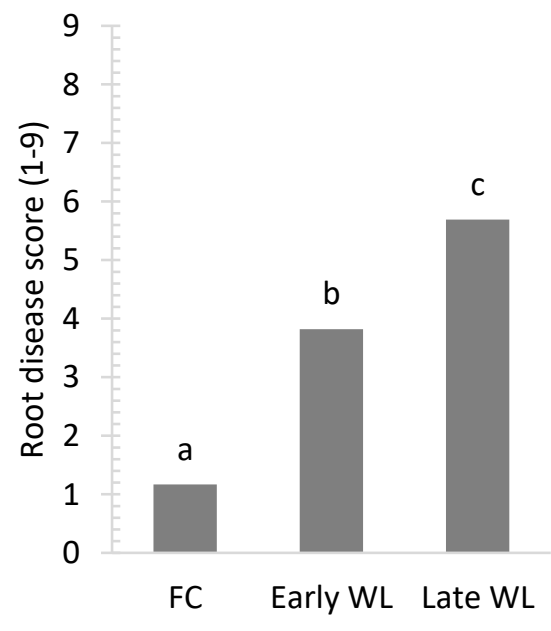

(b)

Figure 2. Main effects of waterlogging (WL) treatments (field capacity (FC), early WL and late WL) on (a) seed weight $(p<0.001)$ and $(\mathbf{b})$ root disease $(1$ good-9 poor $)(p<0.001)$ in a three-way analysis with three chickpea genotypes with or without Phytophthora medicaginis infection. Letters indicate significant differences. 
Table 2. Mean values and 5-95\% CI in parentheses for the three-way GLMM for early and late vegetative waterlogging (WL) and P. medicaginis infection (PRR) for disease and growth parameters of three chickpea genotypes (Geno) C. echinospermum BC PRR moderately resistant 04067, C. arietinum PRR moderately susceptible Yorker and PRR very susceptible Rupali.

\begin{tabular}{|c|c|c|c|c|c|c|}
\hline Water & PRR & Geno & Root Disease & Adventitious Root Count & Biomass $(g) *$ & Seed Weight (g) \\
\hline \multirow{6}{*}{$\begin{array}{c}\text { Field } \\
\text { Capacity }\end{array}$} & \multirow{3}{*}{-} & 04067 & $1(-0.2)$ & $24.5(17.1-31.9)$ & $3.7(3.2-4.2)$ & $0.26(0.14-0.38)$ \\
\hline & & Yorker & $1(-0.2)$ & $34.0(26.6-41.4)$ & $5.4(5.0-5.9)$ & $1.20(1.08-1.33)$ \\
\hline & & Rupali & $1(-0.2)$ & $31.0(23.6-38.4)$ & $6.4(5.9-6.8)$ & $1.27(1.15-1.39)$ \\
\hline & \multirow{3}{*}{+} & 04067 & $1(-0.2)$ & $19.5(12.1-26.9)$ & $3.8(3.3-4.2)$ & $0.34(0.34-0.21)$ \\
\hline & & Yorker & $1.5(0.3-2.7)$ & $29.3(21.8-36.7)$ & $4.6(4.1-5.1)$ & $1.080 .96-1.21)$ \\
\hline & & Rupali & $2.8(1.5-4.0)$ & $27.5(20.1-34.9)$ & $6.7(6.2-7.2)$ & $1.31(1.19-1.43)$ \\
\hline \multirow{6}{*}{ Early WL } & \multirow{3}{*}{-} & 04067 & $2.8(1.5-4.0)$ & $25.8(18.3-33.2)$ & $2.0(1.5-2.4)$ & $0.06(-0.06-0.19)$ \\
\hline & & Yorker & $3.0(1.8-4.2)$ & $28.5(21.1-35.9)$ & $3.1(2.6-3.5)$ & $0.65(0.53-0.77)$ \\
\hline & & Rupali & $3.5(2.3-4.7)$ & $25.0(17.59-2.41)$ & $3.0(2.5-3.5)$ & $0.49(0.37-0.61)$ \\
\hline & \multirow{3}{*}{+} & 04067 & $3.3(2.0-4.5)$ & $34.3(26.8-41.7)$ & $2.3(1.8-2.7)$ & $0.04(-0.08-0.16)$ \\
\hline & & Yorker & $3.5(2.3-4.7)$ & $42.0(34.6-49.4)$ & $3.1(2.6-3.6)$ & $0.43(0.31-0.55)$ \\
\hline & & Rupali & $4.3(3.0-5.5)$ & $36.5(29.1-43.9)$ & $3.1(2.6-3.6)$ & $0.57(0.45-0.69)$ \\
\hline \multirow{6}{*}{ Late WL } & \multirow{3}{*}{-} & 04067 & $4.0(2.8-5.2)$ & $28.3(20.8-35.7)$ & $1.7(1.2-2.2)$ & $0.00(-0.12-0.12)$ \\
\hline & & Yorker & $4.0(2.8-5.2)$ & $49.3(41.8-56.7)$ & $2.2(1.7-2.7)$ & $0.25(0.25-0.12)$ \\
\hline & & Rupali & $5.3(4.0-6.5)$ & $24.5(17.1-31.9)$ & $1.6(1.1-2.0)$ & $0.06(-0.07-0.18)$ \\
\hline & \multirow{3}{*}{+} & 04067 & $6.8(5.5-8.0)$ & $10.8(3.3-18.2)$ & $0.9(0.5-1.4)$ & $0.00(-0.12-0.12)$ \\
\hline & & Yorker & $7.0(5.8-8.2)$ & $18.8(11.3-26.2)$ & $1.4(1.0-1.9)$ & $0.01(-0.11-0.13)$ \\
\hline & & Rupali & $7.3(6.0-8.5)$ & $13.3(5.8-20.7)$ & 1.4(1.0-1.9) & $0.00(-0.12-0.12)$ \\
\hline
\end{tabular}

* Square-root transformed mean predictions.

PRR significantly reduced the seed weight (Figure 3a) and increased the root disease (Figure 3b). In this study, the PRR treatment without waterlogging displayed no foliar evidence of infection or biomass reduction (Table 2); root disease was, however, significantly higher in the very susceptible genotype Rupali, indicating the effectiveness of the PRR inoculation (Table 2).

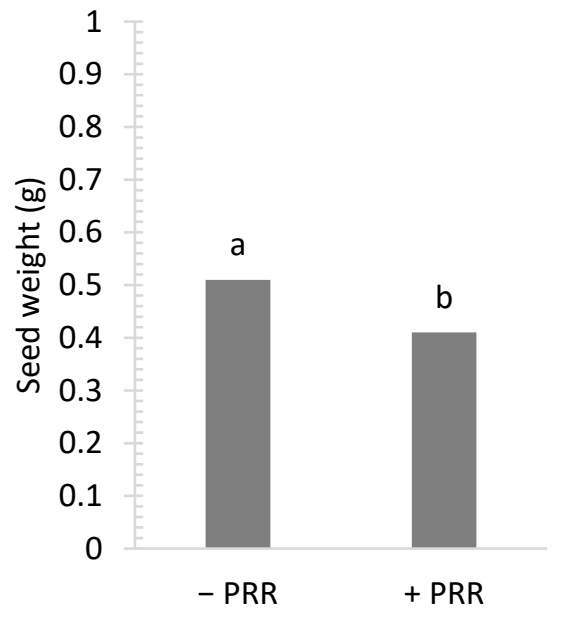

(a)

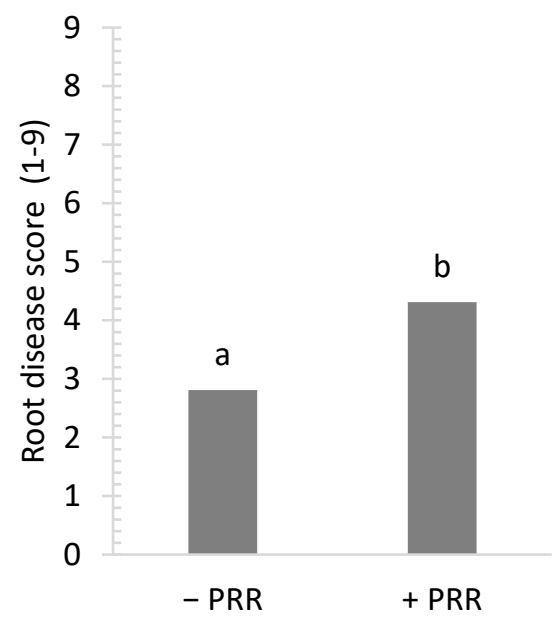

(b)

Figure 3. Main effects of Phytophthora medicaginis infection (PRR) on (a) seed weight $(p<0.001)$ and (b) root disease $(1$ good-9 poor) $(p<0.001)$ in a three-way analysis for three chickpea genotypes and waterlogging (WL) treatments (field capacity (FC), early WL and late WL). Letters indicate significant differences.

Reproductive node count was significantly reduced in all genotypes following both waterlogging and PRR treatments (Table 2); and was most severe following late water- 
logging (3.0), when compared with early waterlogging (6.8) and FC (10.1) treatments, respectively (Figure 4). Wild Cicer BC PRR-resistant 04067 had lower biomass and seed weight reductions across all treatments compared with the other two genotypes examined, including the control, indicating that 04067 suffered the least damage when compared to Rupali and Yorker (Table 2). Interestingly, 04067 had a significantly higher reproductive node count in the control and PRR treatments but set the least amount of seed when compared to Yorker and Rupali (Table 2, Figure 4).

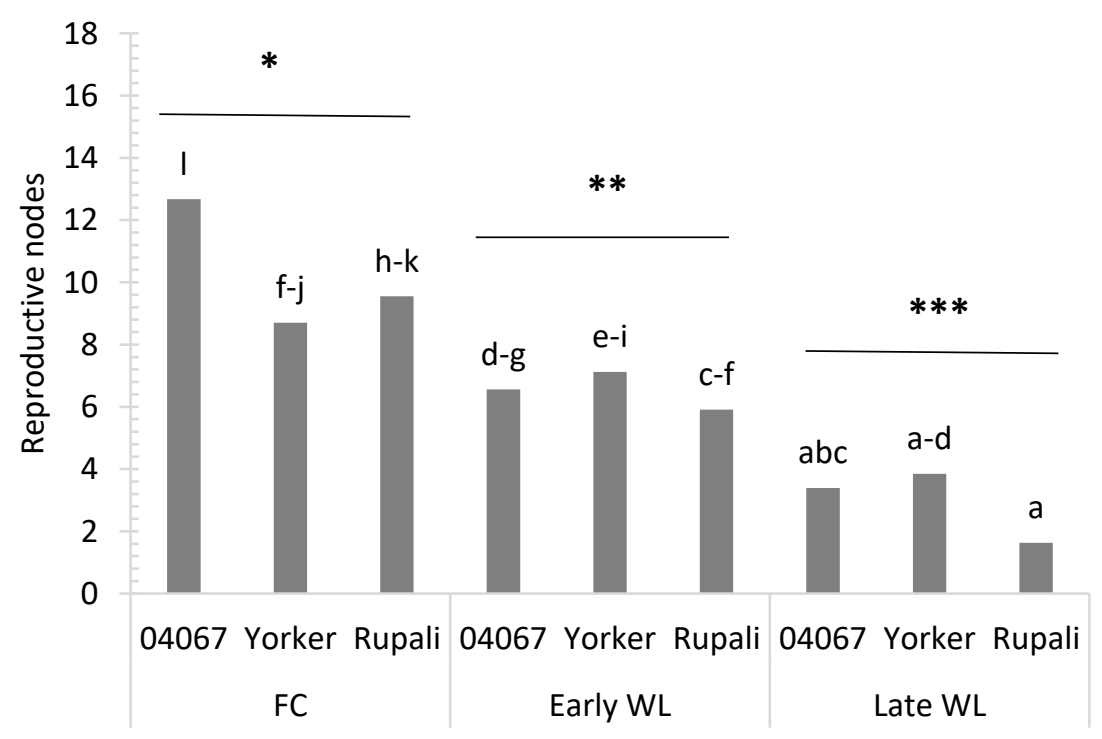

Figure 4. Main waterlogging (WL) and two-way genotype by WL effects on reproductive node count following WL treatments (field capacity (FC), early WL and late WL) for three chickpea genotypes. Letters indicate the significant difference in the two-way interaction $(p<0.001) .{ }^{*},{ }^{* *}$ and ${ }^{* * *}$ indicate significant differences at the main effect level WL $(p<0.001)$.

Late waterlogging (2) resulted in the greatest reduction in rhizobium root nodulation, which was significantly lower than that in the early waterlogging (3) and field capacity (4) treatments (Figure 5). Nodulation in the genotype Rupali was significantly reduced following the late waterlogging and early waterlogging, as well as in Yorker following late waterlogging, when compared with plants maintained at field capacity (Figure 5). No significant reduction in nodulation was evident in 04067, with it having a lower nodulation score under the non-waterlogged FC treatment compared with the other chickpea entries (Figure 5).

Adventitious root counts were significantly lower in PRR inoculation (25.7) treatments compared to non-inoculation (31.4) treatments (Figure 6). Moreover, the adventitious root count was significantly reduced in the PRR and late waterlogging combination treatment, due to PRR root disease (Figure 6, Table 2). The adventitious root count was significantly increased under the late waterlogging PRR treatment in Yorker (31\%), but not in 04067 $(13 \%)$ or Rupali $(20 \%)$, when compared to the control (Table 2$)$. 


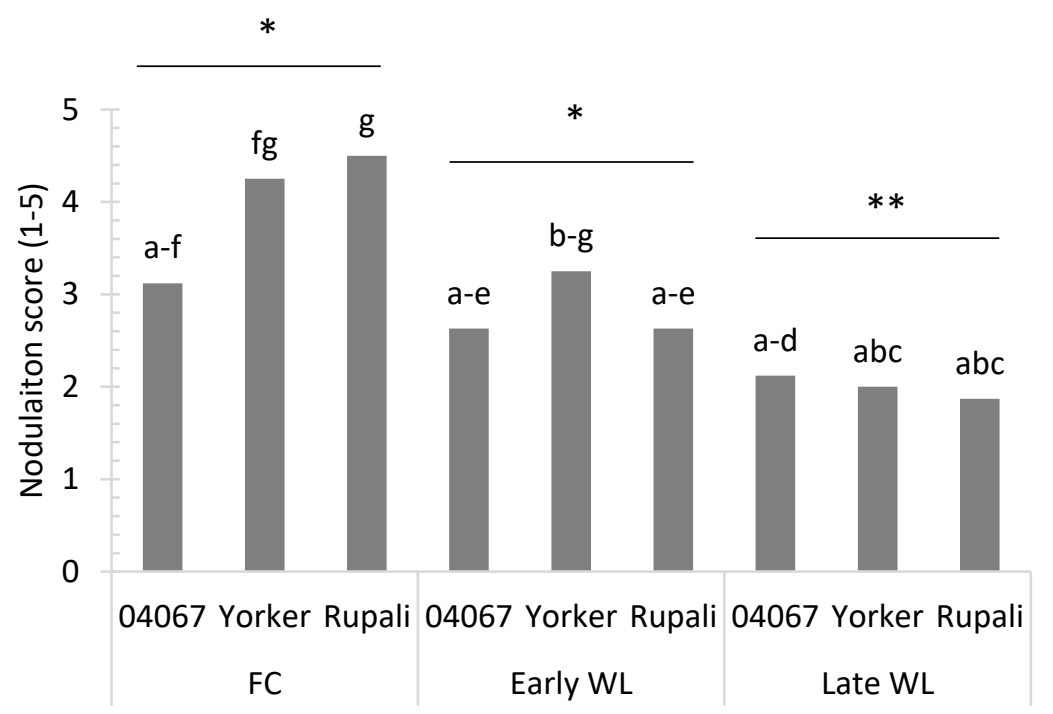

Figure 5. Main waterlogging (WL) and two-way genotype by WL effects on nodulation (1 poor-5 extensive) in three chickpea genotypes following WL treatments (field capacity (FC), early WL and late WL). Letters indicate the significant difference in the two-way interaction $(p<0.001) .{ }^{*}$ and ${ }^{* *}$ indicate significant differences at the main effect level WL $(p<0.001)$.

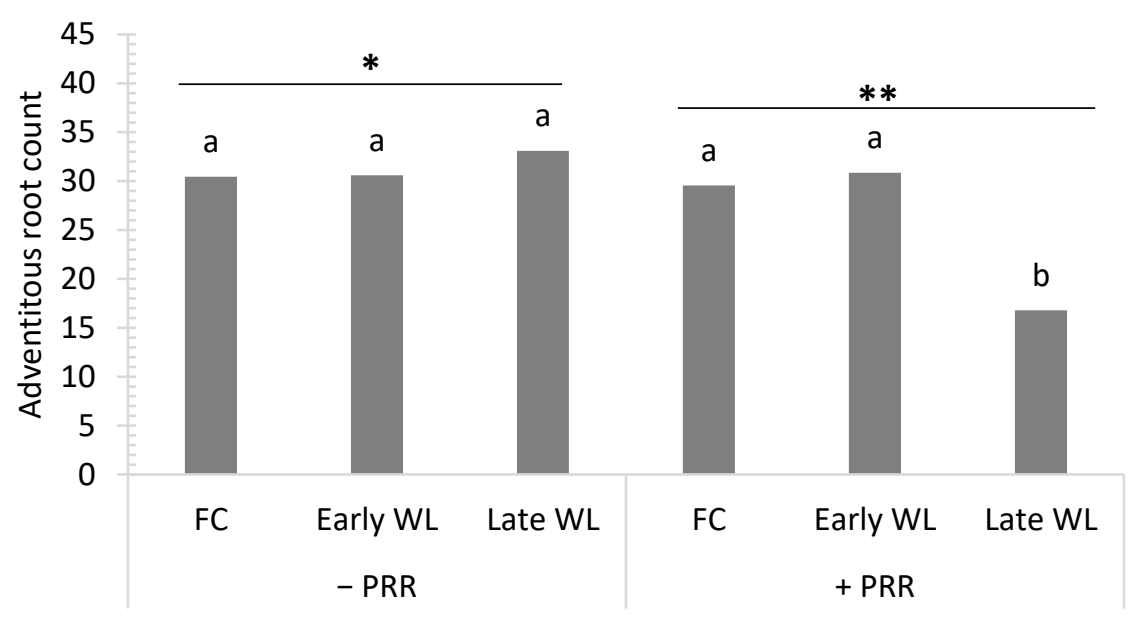

Figure 6. Main Phytophthora medicaginis infection (PRR) and two-way PRR by waterlogging (WL) (field capacity (FC), early and late WL) effects on adventitious root counts in three chickpea genotypes. Letters indicate the significant difference in the two-way interaction $(p<0.05) .{ }^{*}$ and ${ }^{* *}$ indicate significant differences at the main effect level PRR $(p<0.05)$.

Final redox measures $(\mathrm{mV})$ were not significantly different between early and late waterlogging treatments; however, the soil temperature and ambient temperature were $12.1^{\circ} \mathrm{C}$ and $7.8^{\circ} \mathrm{C}$ warmer during the late waterlogging treatment than they were during the early waterlogging treatment, respectively (Figure 7) 


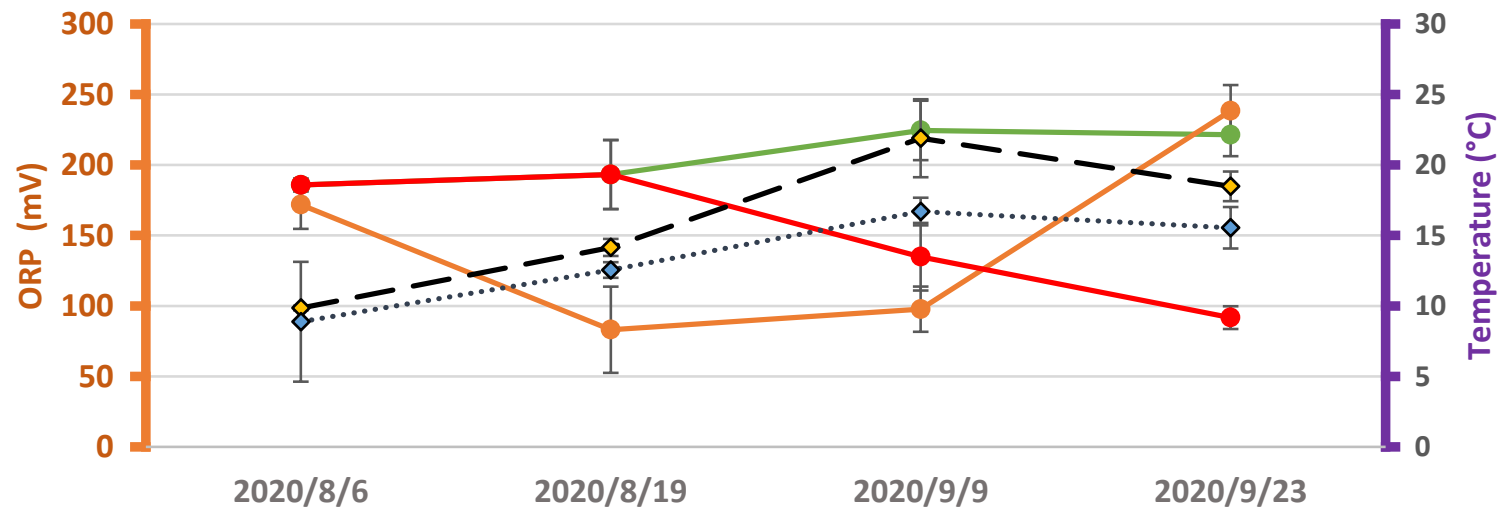

$\longrightarrow \mathrm{Ctrl} \longrightarrow \mathrm{E}-\mathrm{WL} \longrightarrow \mathrm{L}-\mathrm{WL} \longrightarrow$ - Soil temperature $\cdots \diamond \cdots$ Ambient Temperature

Figure 7. Soil oxidation-reduction potential (ORP), ambient and soil temperatures during nonwaterlogged (control), early (E-WL) and late waterlogging (L-WL) treatments in Experiment 1; $\mathrm{pH}$ of $7.6 \pm 0.03$ remained consistent for the duration of experiment.

3.2. Experiment 2: Detection of P. medicaginis DNA in Chickpea Root and Soil Media under Transient and Long-Term Waterlogging Using qPCR

There was no significant difference in $P$. medicaginis kDNA after either the transient waterlogging or long-term waterlogging treatments in the moderately susceptible Yorker and moderately resistant 04067 genotypes (Table 3). An increase in the detected inoculum was observed in the very susceptible genotype Rupali after long-term waterlogging when compared to the treatment with no transient flooding (Table 3). All three genotypes suffered significantly greater root disease, foliar chlorosis and reductions in shoot and root weights under the longer-term waterlogging in the presence of $P$. medicaganis treatment (Table 3).

Table 3. Mean values and 5\%-95\% CI in parentheses for the two-way GLMM for qPCR detection of Phytophthora medicaginis (kDNA copies) growth and disease parameters for three chickpea genotypes: C. echinospermum moderately resistant BC 04067, C. aretinum moderately susceptible Yorker and very susceptible Rupali in potting media infected with P. medicaginis (PRR) under differing flooding regimes.

\begin{tabular}{|c|c|c|c|c|c|c|}
\hline Treatment & Genotype & $\begin{array}{c}\text { Shoot } \\
\text { Weight (g) }\end{array}$ & $\begin{array}{l}\text { Root Weight } \\
\text { (g) }\end{array}$ & $\begin{array}{c}\text { Chlorosis Score } \\
\text { (1-9) }\end{array}$ & $\begin{array}{l}\text { Root Disease } \\
\text { Score (1-9) }\end{array}$ & $\begin{array}{c}\text { P. med kDNA Copies/g } \\
\text { Soil (Log10) }\end{array}$ \\
\hline \multirow{3}{*}{ Control (FC) } & 04067 & $2.5(2.1-2.9)$ & $0.7(0.6-0.8)$ & 1.0 & $1(0.5-1.5)$ & 0 \\
\hline & Yorker & $4.0(3.6-4.4)$ & $0.9(0.8-1.0)$ & 1.0 & $1(0.5-1.5)$ & 0 \\
\hline & Rupali & $4.6(4.2-5.0)$ & $0.9(0.8-1.0)$ & 1.0 & $1(0.5-1.5)$ & 0 \\
\hline \multirow{3}{*}{ PRR (FC) } & 04067 & $2.9(2.5-3.3)$ & $0.8(0.7-0.9)$ & $1.0(0.2-1.8)$ & $1.0(0.5-1.5)$ & $1.5(1.4-1.6)$ \\
\hline & Yorker & $3.8(3.4-4.3)$ & $1.1(1.0-1.2)$ & $1.0(0.2-1.8)$ & $1.0(0.5-1.5)$ & $1.5(1.4-1.6)$ \\
\hline & Rupali & $4.7(4.3-5.1)$ & $1.0(0.9-1.1)$ & $1.3(0.6-2.1)$ & $2.5(2.0-3.0)$ & $1.5(1.4-1.6)$ \\
\hline \multirow{3}{*}{$\begin{array}{c}\text { PRR }+ \text { transient WL } \\
(48 \mathrm{~h})\end{array}$} & 04067 & $2.4(1.9-2.8)$ & $0.7(0.6-0.8)$ & $1.0(0.2-1.8)$ & $1.2(0.7-1.6)$ & $1.6(1.5-1.7)$ \\
\hline & Yorker & $3.3(2.9-3.8)$ & $0.9(0.8-1.0)$ & $1.3(0.6-2.1)$ & $1.5(1.0-2.0)$ & $1.6(1.5-1.7)$ \\
\hline & Rupali & $3.8(3.4-4.3)$ & $0.9(0.8-1.0)$ & $2.2(1.4-3.0)$ & $2.2(1.7-1.6)$ & $1.6(1.5-1.7)$ \\
\hline \multirow{3}{*}{$\begin{array}{c}\text { Inoculated + repeated } \\
\text { transient WL } \\
(48 \mathrm{~h}+48 \mathrm{~h})\end{array}$} & 04067 & $2.2(1.8-2.6)$ & $0.7(0.5-0.7)$ & $1.0(0.2-1.8)$ & $2.5(2.0-3.0)$ & $1.6(1.5-1.7)$ \\
\hline & Yorker & $3.0(2.6-3.5)$ & $0.9(0.8-1.0)$ & $1.8(1.1-2.6)$ & $2.8(2.4-3.3)$ & $1.7(1.6-1.8)$ \\
\hline & Rupali & $3.1(2.7-3.5)$ & $0.9(0.8-1.0)$ & $2.3(1.6-3.1)$ & $3.8(3.4-4.3)$ & $1.7(1.6-1.8)$ \\
\hline \multirow{4}{*}{ PRR + WL (240 h) } & 04067 & $1.6(1.2-2.0)$ & $0.5(0.4-0.7)$ & $2.7(1.9-3.4)$ & $3.8(3.4-4.3)$ & $1.6(1.5-1.7)$ \\
\hline & Yorker & $1.9(1.5-2.3)$ & $0.6(0.5-0.7)$ & $5.0(4.2-5.8)$ & $5.2(4.7-5.6)$ & $1.5(1.4-1.6)$ \\
\hline & Rupali & $1.6(1.2-2.0)$ & $0.5(0.4-0.6)$ & $6.8(6.1-7.6)$ & $6.8(6.4-7.3)$ & $1.8(1.7-1.9)$ \\
\hline & df & & & F-value & & \\
\hline Treatment (T) & 4 & $36.3^{* * *}$ & $10.8^{* * *}$ & $42.1^{* * *}$ & $112.1^{* * *}$ & ${ }^{+} \mathrm{NS}$ \\
\hline Genotype (G) & 2 & $36.9 * * *$ & $19.0^{* * *}$ & $14.6^{* * *}$ & $30.6^{* * *}$ & ${ }^{\dagger} \mathrm{NS}$ \\
\hline $\mathrm{T} \times \mathrm{G}$ & 14 & $2.9 *$ & ${ }^{\dagger} \mathrm{NS}$ & $3.4 *$ & 4.0 * & ${ }^{\dagger} \mathrm{NS}$ \\
\hline
\end{tabular}

FC-field capacity; WL-waterlogging. * Significant at the 0.05 probability level. *** Significant at the 0.001 probability level. ${ }^{\dagger} \mathrm{NS}$, non-significant. 
3.3. Experiment 3: Detection of P. medicaginis Zoospores and PRR in Chickpea under Hypoxic Hydroponic Conditions

P. medicaginis zoospore counts showed that proliferation under hypoxic conditions was not as high as that under the aerated infected treatments when compared to the control (Table 4, Figure 8). Under the combination of hypoxia and P. medicaginis infection, the level of root disease was greater in the very susceptible genotype Rupali but not in the moderately susceptible Yorker or moderately resistant 04067 genotypes. Chlorosis was more severe in all three genotypes in the hypoxic plus PRR infected treatment than it was in the aerated infected or aerated non-infected control (Table 4). Shoot and root weights were significantly reduced in the hypoxic plus PRR infected treatment and aerated infected, consecutively, when compared to the control. Hypoxia appeared to have a greater effect on the severity of PRR's development in the three chickpea genotypes but not on the proliferation of $P$. medicaginis.

Table 4. Mean values and 5-95\% CI in parentheses for the two-way GLMM of hypoxia and P. medicaginis treatments on parameters for three chickpea genotypes C. echinospermum moderately resistant 04067, C. aretinum moderately susceptible Yorker and very susceptible Rupali grown in hydroponic solution.

\begin{tabular}{|c|c|c|c|c|c|}
\hline Treatment & Genotype & Shoot Weight (g) & Root Weight (g) & Chlorosis Score (1-9) & Root Disease Score (1-9) \\
\hline \multirow{3}{*}{$\begin{array}{c}\text { Aerated } \\
\text { control }\end{array}$} & 04067 & $1.8(1.5-2.0)$ & $1.8(1.5-2.3)$ & $1(0.5-1.5)$ & $1(0.5-1.5)$ \\
\hline & Yorker & $2.2(1.9-2.4)$ & $2.8(2.5-3.2)$ & $1(0.5-1.5)$ & $1(0.5-1.5)$ \\
\hline & Rupali & $2.6(2.4-2.6)$ & $3.6(3.2-4.0)$ & $1(0.5-1.5)$ & $1(0.5-1.5)$ \\
\hline \multirow{3}{*}{ Aerated PRR } & 04067 & $1.1(0.9-1.4)$ & $1.9(1.5-2.3)$ & $1(0.5-1.5)$ & $3.2(2.7-3.7)$ \\
\hline & Yorker & $1.2(1.0-1.5)$ & $2.4(2.0-2.7)$ & $1(0.5-1.5)$ & $4.2(3.7-4.7)$ \\
\hline & Rupali & $1.3(1.1-1.52)$ & $2.8(2.4-3.2)$ & $1(0.5-1.5)$ & $4.3(3.9-4.8)$ \\
\hline \multirow{4}{*}{ Hypoxic PRR } & 04067 & $0.5(0.2-0.7)$ & $0.8(0.4-1.2)$ & $2.3(1.9-2.8)$ & $3.7(3.2-4.2)$ \\
\hline & Yorker & $0.4(0.2-0.7)$ & $1.1(0.7-1.4)$ & $2.3(1.9-2.8)$ & $4.2(3.7-4.7)$ \\
\hline & Rupali & $0.6(0.4-0.8)$ & $1.2(0.8-1.6)$ & $3.3(2.9-3.8)$ & $6.8(6.4-7.3)$ \\
\hline & Df & & & F-value & \\
\hline Treatment $(\mathrm{T})$ & 2 & $109.0^{* * *}$ & $53.3 * * *$ & $34.9^{* * *}$ & $267.3^{* * *}$ \\
\hline Genotype (G) & 2 & $5.5 *$ & $16.5^{* * *}$ & ${ }^{\dagger} \mathrm{NS}$ & $36.5^{* * *}$ \\
\hline $\mathrm{T} \times \mathrm{G}$ & 8 & ${ }^{\dagger} \mathrm{NS}$ & ${ }^{\dagger} \mathrm{NS}$ & ${ }^{\dagger} \mathrm{NS}$ & $23.7^{* * *}$ \\
\hline
\end{tabular}

* Significant at the 0.05 probability level. ${ }^{* *}$ Significant at the 0.001 probability level. ${ }^{\dagger}$ NS, non-significant.

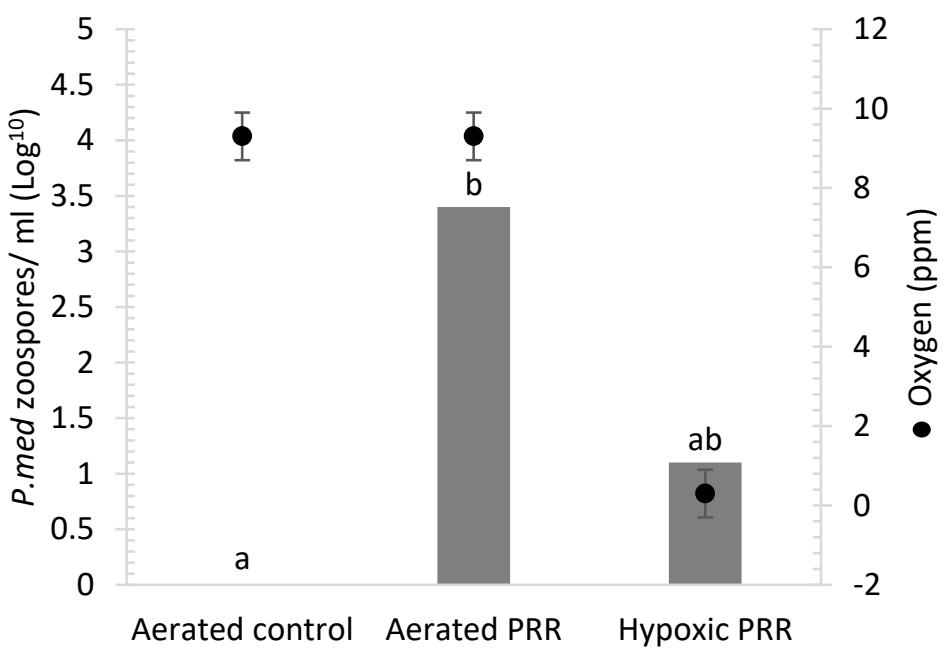

Figure 8. Predicted mean Phytophthora medicaginis (P.med) zoospore counts $(\mathrm{F}=4.2, p<0.05)$ for three aeration $\times$ Phytophthora root rot (P.med) inoculated treatments and the associated oxygen with CI $(\mathrm{ppm})(\mathrm{F}=540.0, p<0.001)$ for a hydroponic chickpea experiment with three genotype sub-treatments listed in Experiment 3. Letters indicate significant differences. 


\section{Discussion}

This study demonstrated that waterlogging in the absence of $P$. medicaginis infection caused severe damage to chickpea plants, including genotypes with a moderate resistance to PRR. Furthermore, late waterlogging had a greater impact than early-season waterlogging, both with and without PRR. Hence, limiting the impact of waterlogging should be a research priority for chickpea breeding and integrated disease management in regions where P. medicaginis is prevalent. The present study found that under long-term waterlogging and in the associated hypoxic conditions, P. medicaginis proliferation and secondary infection (zoospore) failed due to a lack of oxygen, as observed previously in the cases of other Phytophthora spp. [32,33]. Waterlogging increased the likelihood of severe PRR infection, as shown across all experiments and previously reported in the case of lucerne infected with P. medicaginis [34] and oak and avocado infected with P. cinnamomi [35,36]. Kuan and Erwin [34] attributed the greater damage to breaks in the root surface membranes and an increase in the chemotaxis of P. megasperma f. sp. medicaginis zoospores.

Environmental effects such as soil properties and temperature alter the speed at which hypoxia or anoxia is achieved [37]. This study demonstrated that temperature in early and late season waterlogging did not significantly alter the final level of soil reduction and the associated oxygen level in the long-term experiment (Figure 7). This study, however, did not capture the change over time to maximal redox reduction, which may have affected the total amount of time for which both the plant and P. medicaganis were hypoxic in the early and late waterlogging treatments. Soil and ambient temperatures were significantly higher during late waterlogging compared to early waterlogging. Increased soil and ambient temperatures were reported to be important factors in many plant waterlogging systems and are linked to reduced photosynthesis potential, respiration rates and the induction of stress responses, which result in damage and pre-mature senescence [38]. Higher soil and ambient temperatures in late waterlogging may be attributed to severe damage compared to the early waterlogging. In addition, Cowie, et al. [39] found that waterlogging at any age of chickpea plant reduced the yield, but the likelihood of a recovery reduced with the plant's physiological age. This observation is supported by results from this study, i.e., that late waterlogging had a greater effect than early waterlogging.

Environmental factors directly influence the polycyclic soil-borne Phytophthora spp. and the associated disease aggressiveness. In drier environments, the direct germination of oospores results in localized root infections, leading to a low disease pressure. Conversely, soil flooding promotes a rapid oospore germination and the production of sporangia that release large numbers of motile zoospores, initiating multiple root infections and a high disease pressure [32,40]. However, under severe hypoxia $\left(<0.02 \mathrm{~atm} \mathrm{O}_{2}\right)$, as commonly observed under waterlogging conditions, both the mycelial and oospore production is significantly reduced in P. medicaginis [33]. The high disease pressure in the late waterlogging infected treatment may have been associated with the greater hyphal growth prior to late waterlogging or the increase in temperature speeding up the production of zoospores prior to the effects of waterlogging and hypoxia; or, as previously described, it may have been due to the inability of the plant to maintain its defence responses due to the waterlogging damage [41].

Adventitious root counts are reduced significantly following waterlogging in the presence of $P$. medicaganis due to root rot [14]. Following late waterlogging alone, the adventitious root count increased significantly in Yorker and not in 04067. Previously, it was reported that Rupali also demonstrated an increase in adventitious root proliferation [14] however this was not observed in this study. At sites of new root development, the remodelling of the dermal layers provides a temporary entry point for soil-borne Phytophthora spp. along with an attraction to the apex of the new root tissue [10]. Therefore, encouraging root proliferation earlier in the crop season, rather than in response to stress (i.e., waterlogging) or late in the season, may reduce the risk of soil-borne diseases such as PRR and is worthy of further investigation. 
Genotype 04067 had a lower vigour, as reflected in its adventitious root count and biomass, and under the dry finish in the control conditions it did not yield or recover sufficiently from the earlier waterlogging damage. High-vigour genotypes (i.e., Yorker and Rupali) were able to set seed; however, these genotypes are less disease resistant and their recovery was not sufficient to restore their yield potential. The lack of plant and root vigour in 04067 may be linked to the reduced ability of the wild Cicer BC to set seed, due to its poor adaption and indeterminate growth, which has been reported previously as an obstacle when introgressing wild Cicer [16]. Under more moderate PRR conditions, in the absence of waterlogging the moderately susceptible genotype Yorker displays a higher level of PRR resistance compared with the very susceptible genotype Rupali. This further strengthens the concept that there is a difference in the resistance gene mechanisms between the C. arietinum and C. echinospermum genotypes [24]. Pyramiding these resistance mechanisms is possible for providing incremental gains in PRR resistance, but it is important to consider how these low-vigour root growth ideotypes might affect the yield potential and stability of commercial varieties.

Nodulation was lower in the wild Cicer BC 04067 genotype than in Yorker and Rupali in the control treatment, further demonstrating a potential difference in their basal metabolic activity. The metabolites involved in nodulation and root disease resistance among these genotypes are being further investigated in a recombinant inbred line population (data not published). This is an important area of research, which will build on this study, as under late, long-term waterlogging, nodulation is decreased, indicating that the whole root microbiome is altered, such that beneficial and pathogenic microorganism populations are reduced. Incorporating waterlogging tolerance is important to be able to maintain plant metabolism during periods of waterlogging. Traits to consider include an increased lignification and suberisation of the epidermal root tissue to reduce the radial oxygen loss, and an increased aerenchyma to move oxygen into the lower root tissue, as seen in wheat and rice [42-44], thus also removing the need for the production of new adventitious roots that are more vulnerable to PRR infection $[44,45]$.

The pre-breeding effort for chickpea in Australia is currently focused on pyramiding known mechanisms of resistance to PRR with a tolerance of waterlogging. In chickpea there is limited genetic diversity, especially in recognized waterlogging tolerance traits, most likely due to the species origin in semi-arid environments $[12,20,21]$. An opportunity now exists to engineer, via gene editing, additional waterlogging traits identified as beneficial in other plant species into chickpea. Gene editing technology could be used to introduce variation in known waterlogging tolerance genes, such as those shown to be involved in aerenchyma [46] and/or epidermal and endodermal barriers [47].

The level of seedling waterlogging tolerance previously described by Dron et al. [14] in the genotype 04067 appears to be too low to have an industry benefit under late waterlogging conditions, especially in the presence of P. medicaginis. Extending current agronomic controls for waterlogging and PRR beyond the sole recommendation to avoid low-lying paddocks with histories of PRR should be considered if the chickpea industry is to make significant progress towards reducing losses from waterlogging and PRR. The broadscale conservation of the soil structure to reduce waterlogging's occurrence-through farming practices including controlled traffic farming, direct drilling, crop choice and stubble retention-should be recommended [23]. Other more novel agronomic solutions—such as deep ripping, the incorporation of organic matter and other soil amelioration practices - should be investigated to understand their efficacy in reducing waterlogging, whilst taking into consideration the legacy effects within farming systems.

\section{Conclusions}

This study investigated the effects of waterlogging on P. medicaginis infection of chickpea, both of which are common occurrences in the northern grain region of Australia. Previous research indicated that severe PRR disease development resulted from the extreme proliferation of inoculum following flooding events. This study supports the consideration 
that waterlogging itself compromises chickpea plant defences and P. medicaginis growth is restricted by its inability to obtain oxygen requirements under hypoxic conditions during waterlogging. The inability of $P$. medicaginis to proliferate under low-oxygen environments associated with waterlogging and the severity of plant damage incurred by chickpea from early and late season waterlogging alone indicates that waterlogging should be considered a key priority for development and the adoption of improved management strategies. Furthermore, with an expected increase in extreme climatic events and the limited ability to forecast the timing and volumes of rainfall, research should be conducted on both breeding and agronomic practices to reduce the impact of both waterlogging and PRR on chickpea.

Author Contributions: N.D., K.H. and T.S. developed the phenotyping experiments. N.D. conducted the experimentation and drafted the manuscript. K.H., S.S., G.P. and T.S. supervised the project. All authors have read and agreed to the published version of the manuscript.

Funding: NSW Department of Primary Industries and the Grain Research and Development Corporation (GRDC), project number: BLG302.

Institutional Review Board Statement: Not applicable.

Informed Consent Statement: Not applicable.

Data Availability Statement: The data presented in this study are available on request from the corresponding author.

Acknowledgments: This research and Nicole Dron were supported by investment from the Grains Research and Development Corporation and New South Wales Department of Primary Industries, Grains Agronomy and Pathology Partnership (project BLG302). The student's study was supported by the University of Adelaide. The genotype BC 04067-81-2-1-1 was developed in the GRDC and NSW DPI co-invested projects DAN00065 and DAN00094 by Ted Knights. Kevin Moore and Sean Bithell developed the disease assessment and oospore production methods used in this study. Sean Bithell, Toni Petronaitis and Zorica Duric assisted in the editing of this manuscript.

Conflicts of Interest: The authors declare no conflict of interest.

\section{References}

1. Redden, R.; Berger, J. History and origin of chickpea. In Chickpea Breeding and Management; Cromwell Press: Wiltshire, UK, 2007; pp. 1-13.

2. Rea, G.; Laurenzi, M.; Tranquilli, E.; D'Ovidio, R.; Federico, R.; Angelini, R. Developmentally and wound-regulated expression of the gene encoding a cell wall copper amine oxidase in chickpea seedlings. FEBS Lett. 1998, 437, 177-182. [CrossRef]

3. Rawal, V.; Navarro, D. The Global Economy of Pulses; FAO: Rome, Italy, 2019; p. 190.

4. Rees, R.O.; Brouwer, J.B.; Mahoney, J.E.; Walton, G.H.; Brinsmead, R.B.; Knights, E.J.; Beech, D.F. Pea and chickpea production in Australia. In Expanding the Production and Use of Cool Season Food Legumes; Muehlbauer, F.J., Kaiser, W.J., Eds.; Springer: Dordrecht, The Netherlands, 1994; pp. 412-425.

5. Merga, B.; Haji, J. Economic importance of chickpea: Production, value, and world trade. Cogent Food Agric. $2019,5,1615718$. [CrossRef]

6. Hirabayashi, Y.; Mahendran, R.; Koirala, S.; Konoshima, L.; Yamazaki, D.; Watanabe, S.; Kim, H.; Kanae, S. Global flood risk under climate change. Nat. Clim. Change 2013, 3, 816-821. [CrossRef]

7. Food and Agriculture Organization. The Impact of Natural Hazards and Disasters on Agriculture; UN: Rome, Italy, 2015.

8. Bithell, S.; Moore, K.; McKay, A.; Harden, S.; Simpfendorfer, S. Phytophthora root rot of chickpea: Inoculum concentration and seasonally dependent success for qPCR based predictions of disease and yield loss. Australas. Plant Pathol. 2021, 50, 91-103. [CrossRef]

9. Schwinghamer, M.; Southwell, R.; Moore, K.; Knights, E. Phytophthora root rot of chickpea. In Compendium of Chickpea and Lentil Diseases and Pests; The American Phytopathological Society: St Paul, MN, USA, 2011; pp. 22-25.

10. Erwin, D.C.; Bartnicki-Garcia, S.; Tsao, P.H. (Eds.) Phytophthora: Its Biology, Taxonomy, Ecology, and Pathology; American Phytopathological Society: St. Paul, MN, USA, 1983; p. 392.

11. Davison, E.; Tay, F. The effect of aeration on colony diameter, sporangium production and zoospore germination of Phytophthora cinnamomi. New Phytol. 1986, 103, 735-744. [CrossRef]

12. Palta, J.A.; Ganjeali, A.; Turner, N.C.; Siddique, K.H.M. Effects of transient subsurface waterlogging on root growth, plant biomass and yield of chickpea. Agric. Water Manag. 2010, 97, 1469-1476. [CrossRef]

13. Colmer, T.; Voesenek, L. Flooding tolerance: Suites of plant traits in variable environments. Funct. Plant Biol. 2009, 36, 665-681. [CrossRef] 
14. Dron, N.M.; Sutton, T.; Simpfendorfer, S.; Harden, S.; Hobson, K. Phenotyping for waterlogging tolerance as a proxy for Phytophthora medicaginis resistance in chickpea. Plant Health Prog. 2021, 22, 287-293. [CrossRef]

15. Nguyen, V.; Vuong, T.; VanToai, T.; Lee, J.; Wu, X.; Mian, M.R.; Dorrance, A.; Shannon, J.; Nguyen, H. Mapping of quantitative trait loci associated with resistance to Phytophthora sojae and flooding tolerance in soybean. Crop Sci. 2012, 52, 2481-2493. [CrossRef]

16. Knights, E.J.; Southwell, R.J.; Schwinghamer, M.W.; Harden, S. Resistance to Phytophthora medicaginis Hansen and Maxwell in wild Cicer species and its use in breeding root rot resistant chickpea (Cicer arietinum L.). Aust. J. Agric. Res. 2008, 59, 383-387. [CrossRef]

17. Bakker, D.; Hamilton, G.; Houlbrooke, D.; Spann, C. The effect of raised beds on soil structure, waterlogging, and productivity on duplex soils in Western Australia. Soil Res. 2005, 43, 575-585. [CrossRef]

18. Pagliai, M.; Vignozzi, N.; Pellegrini, S. Soil structure and the effect of management practices. Soil Tillage Res. 2004, 79, 131-143. [CrossRef]

19. Croser, J.; Ahmad, F.; Clarke, H.; Siddique, K. Utilisation of wild Cicer in chickpea improvement-progress, constraints, and prospects. Aust. J. Agric. Res. 2003, 54, 429-444. [CrossRef]

20. Chauhan, Y. Screening for tolerance to salinity and waterlogging: Case studies with pigeonpea and chickpea. In Proceedings of the Consultants' Workshop: Adaptation of Chickpea and Pigeonpea to Abiotic Stresses, International Crops Research Institute for the Semi-Arid Tropics, Patancheru, India, 19-21 December 1984.

21. Cowie, A.L.; Jessop, R.S.; MacLeod, D.A. A Study of Waterlogging Damage in Australian Chickpea Cultivars; International Chickpea and Pigeonpea Newsletter; International Crops Research Institute for the Semi-Arid Tropics: Patancheruvu, India, 1995.

22. Brinsmead, R.B.; Rettke, M.L.; Irwin, J.A.G.; Ryley, M.J.; Langdon, P.W. Resistance in chickpea to Phytophthora-megasperma f sp. medicaginis. Plant Dis. 1985, 69, 504-506. [CrossRef]

23. Manik, S.M.N.; Pengilley, G.; Dean, G.; Field, B.; Shabala, S.; Zhou, M. Soil and Crop Management Practices to Minimize the Impact of Waterlogging on Crop Productivity. Front. Plant Sci. 2019, 10, 140. [CrossRef]

24. Amalraj, A.; Taylor, J.; Bithell, S.; Li, Y.; Moore, K.; Hobson, K.; Sutton, T. Mapping resistance to Phytophthora root rot identifies independent loci from cultivated (Cicer arietinum L.) and wild (Cicer echinospermum PH Davis) chickpea. Theor. Appl. Genet. 2019, 132, 1017-1033. [CrossRef]

25. Schwenke, G.; Nachimuthu, G.; Mercer, C.; McPherson, A. Tail-drain sediments are a potential hotspot for nitrous oxide emissions in furrow-irrigated Vertisols used to grow cotton: A laboratory incubation study. J. Environ. Qual. 2020, 49, 14-26. [CrossRef] [PubMed]

26. Corbin, E.; Brockwell, J.; Gault, R. Nodulation studies on chickpea (Cicer arietinum). Aust. J. Exp. Agric. Anim. Husb. 1977, 17, 126-134. [CrossRef]

27. Samineni, S.; Siddique, K.H.; Gaur, P.M.; Colmer, T.D. Salt sensitivity of the vegetative and reproductive stages in chickpea (Cicer arietinum L.): Podding is a particularly sensitive stage. Environ. Exp. Bot. 2011, 71, 260-268. [CrossRef]

28. Amalraj, A.; Taylor, J.; Sutton, T. A hydroponics based high throughput screening system for Phytophthora root rot resistance in chickpea (Cicer arietinum L.). Plant Methods 2019, 15, 82. [CrossRef] [PubMed]

29. Butler, D.; Cullis, B.; Gilmour, A.; Thompson, R. Asreml: An R Package to Fit the Linear Mixed Model; VSNi: Hemel Hempstead, UK, 2018; Available online: https:/ / www.vsni.co.uk/software/asreml (accessed on 16 February 2021).

30. Nielsen, S.; Rogers, S.; Conway, A. Biometry Training: Functions to Assist Design and Analysis of Agronomic Experiments, R Package version 0.8.0; University of Adelaide Biometry Hub: Adelaide, Australia, 2019; Available online: https://biometryhub.github.io/ BiometryTraining/ (accessed on 6 April 2021).

31. Team, R.C. R: A Language and Environment for Statistical Computing; R Version 4.0. 3; R Foundation for Statistical Computing: Vienna, Austria, 2020.

32. Erwin, D.C.; Ribeiro, O.K. Phytophthora Diseases Worldwide; American Phytopathological Society: St. Paul, MN, USA, 1996.

33. Moore, K.J. Oxygen and Carbon Dioxide in the Ecology Phytophthora Species; University of Sydney: Sydney, Australia, 1975.

34. Kuan, T.L.; Erwin, D.C. Predisposition effect of water saturation of soil on Phytophthora root rot of alfalfa. Phytopathology 1980, 70, 981-986. [CrossRef]

35. Jacobs, K.A.; MacDonald, J.D.; Berry, A.M.; Costello, L.R. The effect of low oxygen stress on Phytophthora cinnamomi infection and disease of cork oak roots. In Pillsbury, Norman H.; Verner, Jared; Tietje, William D., Technical Coordinators. 1997. Proceedings of a Symposium on Oak Woodlands: Ecology, Management, and Urban Interface Issues; 19-22 March 1996; San Luis Obispo, CA. Gen. Tech. Rep. PSW-GTR-160; Pacific Southwest Research Station, Forest Service, U.S. Department of Agriculture: Albany, CA, USA, 1997; pp. 553-558.

36. Curtis, D.S.; Zentmyer, G.A. Effect of oxygen supply on Phytophthora root rot of avocado in nutrient solution. Am. J. Bot. 1949, 36, 471-474. [CrossRef]

37. Ponnamperuma, F.N. Effects of flooding on soils. In Flooding and Plant Growth; Academic Press: San Diego, CA, USA, 1984; pp. $10-42$.

38. Xu, L.; Pan, R.; Shabala, L.; Shabala, S.; Zhang, W.-Y. Temperature influences waterlogging stress-induced damage in Arabidopsis through the regulation of photosynthesis and hypoxia-related genes. Plant Growth Regul. 2019, 89, 143-152. [CrossRef]

39. Cowie, A.L.; Jessop, R.S.; MacLeod, D.A. Effects of waterlogging on chickpeas I. Influence of timing of waterlogging. Plant Soil 1996, 183, 97-103. [CrossRef] 
40. Van West, P.; Appiah, A.A.; Gow, N.A. Advances in research on oomycete root pathogens. Physiol. Mol. Plant Pathol. 2003, 62, 99-113. [CrossRef]

41. Stolzy, L.; Sojka, R. Effects of flooding on plant disease. In Flooding and Plant Growth; Academic Press: New York, NY, USA, 1984; pp. 221-264.

42. Colmer, T.D. Long-distance transport of gases in plants: A perspective on internal aeration and radial oxygen loss from roots. Plant Cell Environ. 2003, 26, 17-36. [CrossRef]

43. Jackson, M.; Armstrong, W. Formation of aerenchyma and the processes of plant ventilation in relation to soil flooding and submergence. Plant Biol. 1999, 1, 274-287. [CrossRef]

44. Kotula, L.; Ranathunge, K.; Schreiber, L.; Steudle, E. Functional and chemical comparison of apoplastic barriers to radial oxygen loss in roots of rice (Oryza sativa L.) grown in aerated or deoxygenated solution. J. Exp. Bot. 2009, 60, 2155-2167. [CrossRef]

45. Nishiuchi, S.; Yamauchi, T.; Takahashi, H.; Kotula, L.; Nakazono, M. Mechanisms for coping with submergence and waterlogging in rice. Rice 2012, 5, 2. [CrossRef]

46. Casto, A.L.; McKinley, B.A.; Yu, K.M.J.; Rooney, W.L.; Mullet, J.E. Sorghum stem aerenchyma formation is regulated by SbNAC_D during internode development. Plant Direct 2018, 2, 85. [CrossRef]

47. Ejiri, M.; Fukao, T.; Miyashita, T.; Shiono, K. A barrier to radial oxygen loss helps the root system cope with waterlogging-induced hypoxia. Breed. Sci. 2021, 71, 40-50. [CrossRef] 